\title{
DIE EFFEK VAN DIREKTE INSTRUKSIE OOR VOEGWOORD- GEBRUIK OP DIE SINTAKTIESE KOMPLEKSITEIT VAN NARRATIEWE
}

\author{
Anna-Retha Steinberg, Daleen Klop, en Frenette Southwood \\ Universiteit Stellenbosch
}

\section{INLEIDING}

Blootstelling aan narratiewe vanaf 'n jong ouderdom bevorder geletterdheid en akademiese prestasie (Rollins, McCabe, en Bliss 2000:223). Die vermoë om 'n narratief te produseer behels die gebruik van gevorderde taal- en kognitiewe vaardighede (Wagner, Nettelbladt, Sahlén, en Nilholm 2000:90). Baie akademiese vakke vereis die oorvertel van gebeure, byvoorbeeld in toetse, formele skryfstukke, en mondelinge (Milosky 1987:330). Kinders se vermoë om 'n narratief te verstaan, oor te vertel, en te produseer gee nie net 'n aanduiding van hul algemene taalvermoë nie, maar dien ook as voorbereiding vir die formele taal wat tydens latere skooljare benodig word (Alant, Tesner, en Taljaardt 1992:188).

Verder kan die gebruik van komplekse sintaksis in narratiewe belangrike inligting verskaf oor leerders se skoolgeletterdheidsaktiwiteite (Gutierrez-Clellen en Hofstetter 1994:646; Rollins et al. 2000:223). Sintaktiese kompleksiteit is baie nóú geïntegreer met akademiese taal (Gummersall en Strong 1999:152). Handboeke, naslaanwerke, vraestelle, en wiskundige en wetenskaplike literatuur vereis 'n begrip van en vaardigheid met komplekse taalstrukture. Vir die optimale begrip van byvoorbeeld 'n wiskundige woordprobleem, moet voegwoorde en uitgebreide sinne verstaan en geïnterpreteer kan word. Die mate waarin sintakties komplekse uitinge verstaan word, sal dus 'n invloed hê op die begrip van wetenskaplike of akademiese taal. Onderwyser- en handboektaal word albei toenemend kompleks namate kinders deur hul skoolloopbaan vorder (Gummersall en Strong 1999:152). Die begrip van sintakties komplekse sinne is dus belangrik vir sukses in die klaskamer.

Onlangse navorsing het daarop gedui dat die meerderheid van die leerders uit 'n spesifieke, lae sosio-ekonomiese laerskoolpopulasie aan wie daar deur Universiteit Stellenbosch spraak- 
taalterapiedienste gelewer word, nie sintakties komplekse strukture gebruik in 'n narratiefoorvertel taak nie (Klop en Rumble 2001). Daar is bevind dat die studiepopulasie, bestaande uit 60 leerders in die ouderdomsgroep 5 jaar 8 maande tot 6 jaar 8 maande, feitlik geen saamgestelde sinne gebruik nie (nie in alledaagse kommunikasie nie en ook nie in narratiewe nie), ten spyte daarvan dat hierdie leerders oor 'n begrip van voegwoorde beskik.

Sedert hierdie bevinding gemaak is, is daar twee navorsingsprojekte geloods om die sintaktiese kompleksiteit van hierdie populasie te verhoog. Hierdie studies het bevind dat holistiese, indirekte intervensie slegs 'n beperkte verandering, spesifiek tot sintaktiese kompleksiteit, tot gevolg gehad het (Krantz 2001, Louw 2002). Indirekte behandeling sluit byvoorbeeld dialogiese lees in, waar daar geen direkte klem op die uitbreiding van sinne of die verhoging van kompleksiteit geplaas word nie. 'n Leestegniek word gebruik om soveel as moontlik woordeskat-items en sinstrukture bekend te stel en te modelleer, maar daar word nie van die deelnemers verwag om voorbeelde te herhaal, direk na te boots, of in ander take te gebruik nie. Hierdie tegniek is deur (Krantz 2001) gebruik. 'n Tweede indirekte behandelingstegniek wat gebruik is in 'n poging om die sintaktiese kompleksiteit van hierdie populasie te verhoog, is piktografie. Louw (2002) het deur middel van stokmannetjietekeninge vir die kinders geleer om narratiewe oor te vertel, en het hul narratiewe ontwikkeling en toename in sinskompleksiteit gemeet. Soos Krantz (2001) het Louw (2002) egter ook nie van die deelnemers verwag om voorbeelde te herhaal, direk na te boots, of in soortgelyke take te gebruik nie. 'n Funksionele benadering tot taalintervensie (soos voorgestel deur Owens 1999a) is in hierdie twee studies gebruik. Die resultate van beide studies het slegs geringe toenames in sintaktiese kompleksiteit aangedui.

Studies op ander populasies het getoon dat direkte instruksie wel tot 'n toename in sintaktiese kompleksiteit lei. Goldstein (1984) het byvoorbeeld bevind dat direkte instruksie met inoefening van korrek-geformuleerde sinne goeie resultate gelewer het in die aanleer van nuwe sintaktiese vorme deur tipies-ontwikkelende 4- en 5-jariges. Aangesien Goldstein egter onsinwoorde in sy studie gebruik het, kan die mate waartoe sy bevinding na eerstetaalverwerwingsituasies veralgemeen kan word, bevraagteken word. Gummersall en Strong (1999) het ook bevind dat die modellering en inoefening van spesifieke sintaktiese strukture (nl. onderskikkende en neweskikkende sinsnedes wat deel gevorm het van 'n 
narratief) 'n positiewe invloed op die sintaktiese kompleksiteit van oorvertelde narratiewe van tipies-ontwikkelende 8- en 9-jariges gehad het. Op grond van die resultate van sulke studies, wat getoon het dat direkte instruksie kan lei tot die verhoging van sintaktiese kompleksiteit van ander populasies, is daar besluit om te poog om die sintaktiese kompleksiteit van die populasie aan wie daar deur Universiteit Stellenbosch spraak-taalterapiedienste gelewer word te verhoog deur middel van direkte instruksie, en wel oor die gebruik van voegwoorde.

In hierdie loodsstudie het direkte instruksie die volgende behels: 'n formele verduideliking en modellering van 'n strategie om sinne uit te brei is aan die deelnemers verskaf, waarna hulle voorbeelde van sinne wat voegwoorde bevat, moes herhaal, en gebaseer op hierdie voorbeelde hul eie sinne moes produseer. Indien ongrammatikale sinne geproduseer is of die taak nie korrek uitgevoer is nie, is sinne gekorrigeer.

Daar is in hierdie loodsstudie klem gelê op die aanleer en die gebruik van voegwoorde. Dit is lank reeds bekend dat die manier waarop voegwoorde gebruik word, verander met 'n toename in die gebruiker se ouderdom (cf. bv. Lee 1974:232, 248, 252). Volgens Crystal, Fletcher, en Garman (1989:76) behoort kinders egter reeds op die ouderdom van 3 jaar tot 3 jaar 6 maande gebruik te maak van onderskikkings en neweskikkings. Die belang van die gebruik van voegwoorde word deur Segal en Duchan (1997:96) uitgelig, wat noem dat voegwoorde daartoe bydra om betekenis vir 'n teks te skep en luisteraars help om 'n koherente mentale model van die narratiefgebeure te bou. Voegwoorde soos wanneer, tydens, en nadat in onderskikkende frases verskaf agtergrond vir narratief-gebeure (Gummersall en Strong 1999:153) en verbind dié gebeure op 'n tydsverwante manier (Pelligrini 1985:87), terwyl neweskikkende voegwoorde, soos maar en alhoewel, die semantiese opposisie tussen verskillende gebeure in 'n narratief uitwys (cf. Segal en Duchan 1997:99-116). Die gebruik van onderskikkende en neweskikkende voegwoorde vergemaklik en organiseer informasie en verduidelik verhoudings in taal. Die gebruik van voegwoorde verskaf dus goeie leidrade oor die taalvaardigheid van die gebruiker, en daarom stel Nippold (1993:23) voor dat spraaktaalterapeute taalmonsters moet analiseer vir die voorkoms van voegwoorde.

Weens die belang van narratief-oorvertel in akademiese take is ' $n$ narratief-oorvertel taak in hierdie studie geselekteer as die konteks waarin sintaktiese kompleksiteit gemeet sou word. 
Begrip, wyse van aanbieding, lengte van die narratief, die kind se vorige ondervinding met die narratief, die kind se belangstelling, en die struktuur van die narratief speel 'n rol in hoe suksesvol kinders narratiewe oorvertel. Die gebruik van visuele leidrade (soos prente) in 'n narratief-oorvertel taak verminder geheuelading, maar verskaf geen taalstruktuur nie. Om hierdie rede is daar besluit om van narratief-oorvertel aan die hand van 'n prentreeks gebruik te maak.

In hierdie studie is sintaktiese kompleksiteit gemeet aan die hand van die volgende: (i) die aantal T-eenhede, (ii) gemiddelde lengte van uiting (GLU), (iii) produktiwiteit (d.i., aantal woorde gebruik per narratief), en (iv) Templin se 1957 Structural Complexity Scale, oftewel Strukturele Kompleksiteit Skaal (SKS) ontwikkel uit die werk van McCarthy (1954), soos weergegee deur Vorster (1980:7). Die verskillende voegwoorde wat in die narratief-oorvertel taak gebruik is, is ook getel.

Die breë doel van hierdie loodsstudie was om te bepaal of 'n ses-week lange terapieprogram, bestaande uit direkte instruksie oor die gepaste gebruik van voegwoorde in sinskonteks, effektief is om die gebruik van voegwoorde in narratiewe te verbeter. Die navorsingsprobleem wat hier aangespreek is, is die tekort aan sintaktiese kompleksiteit in narratiewe. Die navorsingsvraag lui of 'n terapieprogram wat gemik is op direkte instruksie van voegwoorde, 'n merkbare verskil sal maak in die sintaktiese kompleksiteit van narratiewe soos oorvertel deur Afrikaanssprekende, 8- tot 9-jarige graad 3-leerders van 'n lae sosio-ekonomiese groep.

\section{METODOLOGIE}

\subsection{Deelnemerseleksie}

Daar is gebruik gemaak van 'n ewekansige steekproeftrekking met terugplasing om 10 leerders uit dieselfde graad 3-klas by 'n skool in die landelike omgewing van Stellenbosch te selekteer. Volgens die Hersiende Nasionale Kurrikulum vorm graad 3 deel van die grondslagfase, waarin mondelinge taalproduksie ' $n$ belangrike aktiwiteit is. Om hierdie rede is graad 3-leerders geselekteer. Die deelnemers moes nog nooit 'n skooljaar herhaal het nie, om sodoende te kontroleer vir ernstige leerprobleme en groot kognitiewe agterstande. Alle 
deelnemers moes tussen die ouderdom van 8 jaar 5 maande en 9 jaar 5 maande wees om te kontroleer vir die rol van ouderdom in reseptiewe taalontwikkeling. Hierdie ouderdomsgroep is geselekteer omdat kinders volgens Owens (1999b:355) teen 9 jaar reeds die elemente van storiegrammatika en storie-inhoud behoort te kan produseer. Die deelnemers moes almal moedertaalsprekers van Afrikaans wees. Afrikaanssprekendes is geselekteer omdat Afrikaans volgens die 1996-sensusresulte die taal is wat as moedertaal gepraat word deur die meerderheid (59\%) van die inwoners van Wes-Kaapland (Statistics South Africa 1999), waar die deelnemers woonagtig was. Deelnemers moes ook normale gehoor en normale vlotheid gehad het. Verder mag deelnemers geen vorige verwysing na of behandeling deur 'n spraaktaalterapeut gehad het nie, om enige vorige narratief-intervensie uit te skakel en die deelnemers vergelykbaar te maak. Verder moes alle deelnemers se reseptiewe woordeskatvlak binne dieselfde standaardtelling ekwivalent omvang wees, naamlik tussen 54 en 66 soos bepaal deur die Afrikaanse Reseptiewe Woordeskattoets (ARW, Buitendag 1993), om te kon kontroleer vir verskille in reseptiewe taalvermoëns.

Die tien geselekteerde deelnemers is dan gelykop ewekansig verdeel, met terugplasing, in 'n eksperimentele (terapie-) en 'n kontrolegroep, met vyf leerders in elke groep. Een rede waarom klein groepe gebruik is, is omdat Landgarten (1981:106) bevind het dat leerders in kleiner groepsverband beter en meer kreatief funksioneer, onder andere omdat leerders by mekaar leer. Verder vind spraak-taalterapie tradisioneel óf individueel óf in klein groepe plaas, sodat oordrag en vordering makliker gemonitor kan word, en meer individuele aandag aan kliënte gegee kan word. Om dus verhoogde veralgemeenbaarheid van die bevindinge na die kliniese praktyk te bewerkstellig, en op grond van Whitehurst, Arnold, Epstein, Angell, Smith, en Fischel (1994:687) se voorstel dat terapiegroepe nie meer as vyf leerders behoort te bevat nie, is die grootte van die groepe in hierdie studie tot vyf beperk.

\subsection{Deelnemers}

Die tien graad 3-leerders wat uiteindelik as deelnemers in die loodsstudie ingesluit is, was tussen 8 jaar 5 maande en 9 jaar 1 maand oud (gemiddelde ouderdom 8 jaar 8 maande). Vyf van die deelnemers was vroulik en vyf manlik. Alle deelnemers se ouers was lede van die laesosio-ekonomiese groep (cf pp 159). Die deelnemers het roupunte van 70 tot 94 (gemiddeld 
82,7) op die ARW behaal, wat omgeskakel kan word na 'n ARW-ouderdom van 5 jaar 2 maande tot 6 jaar 9 maande (gemiddeld 6 jaar 1 maand). Die standaardtelling-ekwivalent van 54 tot 66 (gemiddeld 59.6), wat behaal is deur die populasie waaruit die deelnemers geselekteer is, is twee standaardafwykings onder die gemiddeld, wat aandui dat die populasie volgens die ARW met 'n reseptiewe taalagterstand presenteer.

\subsection{Eksperimentele protokol}

\subsubsection{Navorsingsontwerp}

Hierdie loodsstudie was quasi-eksperimenteel. Die eksperimentele groep het behandeling ontvang, terwyl die kontrole groep geen behandeling ontvang het nie. 'n Voor- en na-toetsing van beide groepe se narratiewe tydens 'n narratief-oorvertel taak is uitgevoer om die effektiwiteit van 'n behandelingsprogram, wat direkte instruksie en opleiding in die gebruik van voegwoorde behels het, te bepaal.

\subsubsection{Prosedures}

Nadat die nodige toestemming vir deelname van die onderwysdepartement, skoolhoof, ouers en die 10 deelnemers self verkry is, is gehoorsifting asook die ARW op die deelnemers uitgevoer, waarna elke deelnemer se narratief-oorvertel vermoëns individueel geëvalueer is. Sodoende is die moontlikheid uitgeskakel dat leerders tydens evaluering by mekaar kon leer. Hierna het die vyf lede van die eksperimentele groep vir ses weke lank (die tyd beskikbaar vir die versameling van data in hierdie loodsstudie) twee maal per week vir 30 minute per keer in groepsverband direkte instruksie ontvang oor die gebruik van voegwoorde. Ná die ses weke is al tien deelnemers se narratief-oorvertel vermoëns herevalueer en is 'n vergelyking tussen die voor- en natoetsresultate gemaak. Om etiese redes is dieselfde direkte intervensie na afloop van die loodsstudie ook aan die kontrolegroep gegee. Alle prosedures is deur die eerste navorser uitgevoer. 


\subsubsection{Evaluasie}

Tydens evaluasie het die navorser met behulp van prentkaarte 'n narratief vertel, waarna die deelnemer dit aan die hand van dieselfde prentkaarte moes oorvertel. Hierdie proses is herhaal met ' $n$ tweede narratief om die verkreë data meer verteenwoordigend van die deelnemers se narratiewe vermoëns te makk. Die twee narratiewe wat gebruik is, was 'n aangepaste weergawe van Die mier en die duif (Smallman en Nestling 1993, cf. bylaag A) en 'n aangepaste weergawe van 'n storie uit die Oxford Storieboom-reeks (fase 3 nommer 1), Op die strand (Hunt en Brychta 1999, cf. bylaag B). Hierdie narratiewe is geselekteer omdat hulle ouderdomstoepaslik is en omdat die storieboeke aantreklike prente het. Die narratiewe is aangepas deur meer voegwoorde in hulle in te voeg om sodoende die verband tussen die narratief-gebeure duidelik te maak (en nie bloot die gebeure as 'n onverwante lys aan te bied nie). $\mathrm{Na}$ afloop van die ses-week lange terapieprogram is dieselfde narratiewe weer aan elke deelnemer individueel vertel en deur elke deelnemer individueel oorvertel. 'n Bandopname is van elke narratief van elke deelnemer gemaak. (Cf. bylaag $\mathrm{C}$ vir voorbeelde van deelnemers se narratiewe.)

\subsubsection{Instruksie}

Elke sessie van direkte instruksie het dieselfde formaat gehad. Om die sessie te begin het die navorser die aktiwiteit aan die deelnemers duidelik gemaak deur te modelleer wat sy van hulle verwag het. Sy het 'n sin oor 'n prent geverbaliseer (bv. Die brandweerman spuit water), 'n ander sin oor 'n tweede prent geverbaliseer (bv. Die kar is aan die brand), 'n kaartjie met een voegwoord (bv. want) daarop geneem, en dan die twee sinne met die geteikende voegwoord gekombineer (bv. Die brandweerman spuit water want die kar is aan die brand). Hierna is die prosedure herhaal met die volgorde van die prentjies omgeruil sodat die twee sinne op 'n ander manier met die geteikende voegwoord gekombineer is (bv. Die kar is aan die brand want die brandweerman het nog nie orals water gespuit nie). Op hierdie manier is die proefpersone aan twee verskillende gebruiksmoontlikhede van elke geteikende voegwoord blootgestel voordat daar van hulle verwag is om self hierdie voegwoord in sinne te gebruik.

Hierna het elk van die lede van die eksperimentele groep 'n prent ontvang, waaroor hulle individueel ' $n$ sin moes verbaliseer. Sodra al vyf hul sinne aan mekaar voorgesê het, het elkeen 'n tweede prent ontvang, waaroor hulle ook 'n sin moes maak en aan mekaar voorsê. 
Hierna het die navorser 'n woordkaartjie aan elk gegee, met die voegwoord wat die dag behandel sou word daarop. Die voegwoorde en en nadat is elk vir een sessie lank geteiken, terwyl maar, want, omdat, sodat, en voordat elk vir twee sessies geteiken is. Deelnemers het beurte gekry waarin hulle hul eie twee sinne, oor hul eie twee prente, moes kombineer met die geteikende voegwoord. Sodra 'n deelnemer dit gedoen het, en foute gekorrigeer is, moes al die deelnemers die sinne herhaal. Hierna het elke deelnemer nuwe prente ontvang en is die prosedure (sonder dat die navorser weer die aktiwiteit gemodelleer het) met dieselfde voegwoord vir die res van die sessie (ongeveer 10 maal) herhaal.

\subsubsection{Data-transkripsie en -analise}

Daar is ' $\mathrm{n}$ tekort aan gestandaardiseerde toetse waarmee die ekspressiewe taalvaardighede van Afrikaanssprekende 8- en 9-jariges op 'n geldige en betroubare wyse gemeet kan word. Om verskeie redes (bv. norme wat van 'n populasie wat van hierdie populasie verskil, verkry is, swak betroubaarheid, en onvoldoende monstergrootte) sou die beskikbare gestandaardiseerde instrumente nie 'n akkurate profiel van die deelnemers se ekspressiewe taalvaardighede gelewer het nie. Daarom is 'n self-opgestelde protokol in hierdie studie gebruik. Die feit dat daar nie van gestandaardiseerde meetinstrumente gebruik gemaak is nie, kon egter die geldigheid van die resultate negatief beïnvloed het.

Elkeen van die deelnemers se narratiewe is ortografies getranskribeer, waarna dit in Teenhede gesegmenteer is volgens die metode voorgestel in Vorster (1980). 'n T-eenheid bestaan uit 'n hoofsin en al die frases en onderskikkende bysinne wat daarby mag hoort. 'n Newegeskikte sin vorm 'n aparte T-eenheid.

Hierna is die narratiewe geanaliseer in terme van produktiwiteit, wat verwys na die totale aantal woorde wat in die narratief gebruik is. Die gemiddelde lengte van uitinge (GLU), gemeet in woorde, is vervolgens bepaal, waar 'n uiting as 'n T-eenheid geneem is, soos voorgestel in Vorster (1980).

Hierna is die narratiewe geanaliseer in terme van hul strukturele kompleksiteit soos gemeet deur die SKS. Volgens hierdie skaal word daar vir elke uiting 'n enkel syfer gewig toegeken, soos volg: 0 = onvoltooide uiting; 1 = enkelvoudige $\sin ; 2$ = enkelvoudige sin met twee of 
meer frases; 3 = sinne met neweskikkings; en 4 = sinne met onderskikkings. Elke uiting is volgens hierdie skaal bepunt, en aan die einde van die narratief is die toegekende punte bymekaar getel. ' $n$ Beperking van hierdie skaal is dat dit net 'n algemene indruk van die deelnemers se taalkompleksiteit gee. Dit kan dus net vir siftings- en vergelykingdoeleindes gebruik word.

Vervolgens is daar ' $\mathrm{n}$ telling gemaak van die aantal sinne met neweskikking en die aantal met onderskikking. Laastens is die aantal voegwoorde getel waaroor direkte instruksie gegee is en wat ook in die deelnemers se narratiewe voorgekom het, beide voor en na instruksie.

\subsection{Statistiese ontleding}

Vir metings van aantal T-eenhede, produktiwiteit, GLU, en sintaktiese kompleksiteit is 'n herhaalde behandelings- een-rigting analise van variansie (ANOVA) uitgevoer om te bepaal of die verskil tussen die voor- en natoetsresultate van die twee groepe beduidend was. 'n Alpha-vlak van 0.05 is deurgaans gebruik. Hierdie data is dus wel statisties verwerk, maar, aangesien die aantal deelnemers aan hierdie loodsstudie baie klein was, is 'n kwalitatiewe analise van die data ook gemaak om die kwantitatiewe analise aan te vul en te bepaal of verskille wat statisties beduidend is ook klinies beduidend sou wees. Verbetering van voor- na natoetsresultate is as klinies beduidend beskou as die verbetering van so ' $n$ aard was dat dit ' $n$ verskil in die deelnemer se taalgebruik sou meebring. 'n Toename in gebruik van neweskikkende voegwoorde wat statisties beduidend is, maar in der waarheid die verskil is tussen een voegwoord per narratief in die voortoets teenoor twee in die natoets, is byvoorbeeld nie as klinies beduidend beskou nie, omdat die gebruik van twee voegwoorde in 'n narratief wat goeie geleentheid bied vir die gebruik van 25 voegwoorde steeds nie as goeie voegwoordgebruik beskou word nie. So 'n klein verskil tussen voor- en natoetstellings van voegwoordgebruik word dus nie beskou as 'n verbetering wat 'n werklike verskil in die deelnemer se taalgebruik sou meebring nie.

Die resultate van die metings van aantal newegeskikte en ondergeskikte sinne asook die aantal voegwoorde is nie statisties verwerk nie, aangesien sulke verwerkings nie sinvol sou wees met die klein groep, die lae routellings, en die groot hoeveelhede nul-tellings nie. In die geval 
van hierdie metings is daar slegs besluit of die verskil tussen groepe klinies beduidend sou wees al dan nie.

\section{RESULTATE}

Die resultate van die tellings van T-eenhede, die aantal woorde per narratief, die GLU, asook die strukturele kompleksiteit, aantal sinne met neweskikking en onderskikking, en die aantal voegwoorde wat in die deelnemers se narratiewe voorgekom het, word in hierdie afdeling bespreek.

Tabel 1 toon die aantal T-eenhede gebruik in die narratiewe tydens die voor- en natoets van beide die eksperimentele- en kontrolegroep. Vir beide narratiewe het die eksperimentele groep ' $\mathrm{n}$ groter toename getoon in die aantal T-eenhede wat tydens die natoets verkry is as wat die kontrolegroep getoon het. Geen van hierdie veranderinge was egter klinies of statisties beduidend nie (vir Die mier en die duif: $F(1,8)=0.063, p=0.81$; vir Op die strand: $F(1,8)=$ 4.023, $p=0.08$; vir albei narratiewe saam: $F(1,8)=2.579, p=0.15)$.

Tabel 1. Aantal T-eenhede

\begin{tabular}{|c|c|c|c|c|c|c|c|c|c|c|c|}
\hline \multicolumn{6}{|c|}{ DIE MIER EN DIE DUIF } & \multicolumn{6}{|c|}{ OP DIE STRAND } \\
\hline \multicolumn{3}{|c|}{$\begin{array}{l}\text { Eksperimentele } \\
\text { groep }\end{array}$} & \multicolumn{3}{|c|}{ Kontrolegroep } & \multicolumn{3}{|c|}{$\begin{array}{c}\text { Eksperimentele } \\
\text { groep }\end{array}$} & \multicolumn{3}{|c|}{ Kontrolegroep } \\
\hline D & $\begin{array}{l}\text { Voor- } \\
\text { toets }\end{array}$ & $\begin{array}{c}\text { Na- } \\
\text { toets }\end{array}$ & D & $\begin{array}{l}\text { Voor- } \\
\text { toets }\end{array}$ & $\begin{array}{c}\text { Na- } \\
\text { toets }\end{array}$ & D & $\begin{array}{l}\text { Voor- } \\
\text { toets }\end{array}$ & $\begin{array}{c}\text { Na- } \\
\text { toets }\end{array}$ & D & $\begin{array}{l}\text { Voor- } \\
\text { toets }\end{array}$ & $\begin{array}{l}\text { Na- } \\
\text { toets }\end{array}$ \\
\hline 1 & 17 & 19 & 6 & 16 & 18 & 1 & 15 & 19 & 6 & 12 & 12 \\
\hline 2 & 17 & 18 & 7 & 10 & 10 & 2 & 15 & 18 & 7 & 9 & 11 \\
\hline 3 & 18 & 18 & 8 & 10 & 11 & 3 & 17 & 21 & 8 & 16 & 15 \\
\hline 4 & 14 & 17 & 9 & 16 & 16 & 4 & 12 & 19 & 9 & 11 & 15 \\
\hline 5 & 20 & 19 & 10 & 14 & 15 & 5 & 20 & 21 & 10 & 13 & 14 \\
\hline Omv & $14-20$ & $17-19$ & & $10-16$ & $10-18$ & & $12-20$ & 18-21 & & $9-16$ & $11-15$ \\
\hline Gem & 17,2 & 18,2 & & 13,2 & 14 & & 15,8 & 19,6 & & 12,2 & 13,4 \\
\hline
\end{tabular}

Nota: $\mathrm{D}=$ deelnemer, Omv = omvang; Gem = gemiddeld

Tabel 2 toon die totale aantal woorde gebruik in die narratiewe tydens die voor- en natoets van beide die eksperimentele- en kontrolegroep. By beide narratiewe was daar 'n toename in die aantal woorde per narratief, maar hierdie toename was nie klinies of statisties beduidend nie (vir Die mier en die duif: $F(1,8)=0.136, p=0.72$; vir Op die strand: $F(1,8)=2.596, p=$ 
0.15; vir albei narratiewe saam: $F(1,8)=2.708, p=0.14)$. Dit is egter interessant om daarop te let dat die kontrolegroep se totale aantal woorde tydens voortoetsing in beide narratiewe minder was as dié van die eksperimentele groep.

Tabel 2. Totale aantal woorde (produktiwiteit)

\begin{tabular}{|c|c|c|c|c|c|c|c|c|c|c|c|}
\hline \multicolumn{6}{|c|}{ DIE MIER EN DIE DUIF } & \multicolumn{6}{|c|}{ OP DIE STRAND } \\
\hline \multicolumn{3}{|c|}{$\begin{array}{l}\text { Eksperimentele } \\
\text { groep }\end{array}$} & \multicolumn{3}{|c|}{ Kontrolegroep } & \multicolumn{3}{|c|}{$\begin{array}{c}\begin{array}{c}\text { Eksperimentele } \\
\text { groep }\end{array} \\
\end{array}$} & \multicolumn{3}{|c|}{ Kontrolegroep } \\
\hline D & $\begin{array}{l}\text { Voor- } \\
\text { toets }\end{array}$ & $\begin{array}{l}\text { Na- } \\
\text { toets }\end{array}$ & D & $\begin{array}{l}\text { Voor- } \\
\text { toets }\end{array}$ & $\begin{array}{l}\text { Na- } \\
\text { toets }\end{array}$ & D & $\begin{array}{l}\text { Voor- } \\
\text { toets }\end{array}$ & $\begin{array}{c}\text { Na- } \\
\text { toets }\end{array}$ & D & $\begin{array}{l}\text { Voor- } \\
\text { toets }\end{array}$ & $\begin{array}{l}\text { Na- } \\
\text { toets }\end{array}$ \\
\hline 1 & 115 & 131 & 6 & 89 & 109 & 1 & 116 & 135 & 6 & 77 & 78 \\
\hline 2 & 124 & 137 & 7 & 69 & 82 & 2 & 111 & 122 & 7 & 64 & 66 \\
\hline 3 & 136 & 148 & 8 & 56 & 61 & 3 & 119 & 144 & 8 & 117 & 121 \\
\hline 4 & 95 & 106 & 9 & 96 & 98 & 4 & 85 & 152 & 9 & 67 & 82 \\
\hline 5 & 113 & 113 & 10 & 98 & 102 & 5 & 123 & 129 & 10 & 70 & 85 \\
\hline $\mathrm{Omv}$ & $\begin{array}{l}95- \\
136\end{array}$ & $\begin{array}{l}106- \\
148\end{array}$ & & $\begin{array}{c}56- \\
98\end{array}$ & $\begin{array}{l}61- \\
109\end{array}$ & & $\begin{array}{l}85- \\
123\end{array}$ & $\begin{array}{l}122- \\
152\end{array}$ & & $\begin{array}{l}64- \\
117\end{array}$ & $\begin{array}{l}66- \\
121\end{array}$ \\
\hline Gem & 116,6 & 127 & & 81,6 & 90,4 & & 110,8 & 136,4 & & 79 & 86,4 \\
\hline
\end{tabular}

Nota: $\mathrm{D}=$ deelnemer, Omv = omvang; Gem = gemiddeld

Tabel 3 toon dat die GLU van die deelnemers se narratiewe van beide groepe nie ' $n$ toename getoon het vanaf die voor- na die natoets nie. Statistiese analise van die data het op dieselfde gedui (vir Die mier en die duif: $F(1,4)=0.173, p=0.69$; vir Op die strand: $F(1,4)=0.017, p$ $=0.90$; vir albei narratiewe saam: $F(1,4)=0.500, p=0.50)$.

Tabel 3. Gemiddelde lengte van uitinge (GLU)

\begin{tabular}{|c|c|c|c|c|c|c|c|c|c|c|c|}
\hline \multicolumn{6}{|c|}{ DIE MIER EN DIE DUIF } & \multicolumn{6}{|c|}{ OP DIE STRAND } \\
\hline \multicolumn{3}{|c|}{$\begin{array}{c}\text { Eksperimentele } \\
\text { groep }\end{array}$} & \multicolumn{3}{|c|}{ Kontrolegroep } & \multicolumn{3}{|c|}{$\begin{array}{c}\text { Eksperimentele } \\
\text { groep }\end{array}$} & \multicolumn{3}{|c|}{ Kontrolegroep } \\
\hline $\mathbf{D}$ & $\begin{array}{l}\text { Voor- } \\
\text { toets }\end{array}$ & $\begin{array}{c}\text { Na- } \\
\text { toets }\end{array}$ & D & $\begin{array}{l}\text { Voor- } \\
\text { toets }\end{array}$ & $\begin{array}{c}\text { Na- } \\
\text { toets }\end{array}$ & $\mathbf{D}$ & $\begin{array}{l}\text { Voor- } \\
\text { toets }\end{array}$ & $\begin{array}{c}\text { Na- } \\
\text { toets }\end{array}$ & D & $\begin{array}{l}\text { Voor- } \\
\text { toets }\end{array}$ & $\begin{array}{c}\text { Na- } \\
\text { toets }\end{array}$ \\
\hline 1 & 6.8 & 6.9 & 6 & 5.6 & 5.9 & 1 & 7.7 & 7.1 & 6 & 6.4 & 6.5 \\
\hline 2 & 7.3 & 7.6 & 7 & 6.9 & 8.2 & 2 & 7.4 & 6.8 & 7 & 7.1 & 6 \\
\hline 3 & 7.6 & 8.2 & 8 & 5.6 & 5.5 & 3 & 7 & 6.9 & 8 & 7.3 & 8.1 \\
\hline 4 & 6.8 & 6.2 & 9 & 6 & 6.1 & 4 & 7.1 & 8 & 9 & 6.1 & 5.5 \\
\hline 5 & 5.7 & 6 & 10 & 7 & 6.8 & 5 & 6.2 & 6.2 & 10 & 5.4 & 6.1 \\
\hline Omv & $5.7-7.6$ & $6-8.2$ & & 5.6-7 & $5.5-8.2$ & & $6.2-7.7$ & $6.2-7.1$ & & $5.4-7.3$ & $5.5-8.1$ \\
\hline Gem & 6,8 & 7 & & 6,2 & 6,5 & & 7,1 & 7 & & 6,5 & 6,4 \\
\hline
\end{tabular}

Nota: $\mathrm{D}=$ deelnemer, Omv = omvang; Gem = gemiddeld 
Tabel 4 toon die strukturele kompleksiteit, soos gemeet deur die SKS, van die narratiewe tydens die voor- en natoets van die twee groepe. Slegs die totale tellings van die verskillende deelnemers word in hierdie tabel weergegee. Dit blyk dat daar ' $n$ baie klein verbetering by albei narratiewe van die eksperimentele groep plaasgevind het, maar dat daar nie 'n merkbare toename in die kontrolegroep se strukturele kompleksiteit was nie. Die verskil tussen die twee groepe was telkens statisties beduidend (vir Die mier en die duif: $F(1,4)=11.267, p=0.01$; vir Op die strand: $F(1,4)=9.308, p=0.02$; vir albei narratiewe saam: $F(1,4)=43.750, p=$ 0.0002). Vir albei narratiewe was die voortoets-tellings vir strukturele kompleksiteit van die kontrolegroep swakker as dié van die eksperimentele groep.

Tabel 4. Strukturele kompleksiteit (totale telling)

\begin{tabular}{|c|c|c|c|c|c|c|c|c|c|c|c|}
\hline \multicolumn{6}{|c|}{ DIE MIER EN DIE DUIF } & \multicolumn{6}{|c|}{ OP DIE STRAND } \\
\hline \multicolumn{3}{|c|}{$\begin{array}{c}\begin{array}{c}\text { Eksperimentele } \\
\text { groep }\end{array} \\
\end{array}$} & \multicolumn{3}{|c|}{ Kontrolegroep } & \multicolumn{3}{|c|}{$\begin{array}{c}\begin{array}{c}\text { Eksperimentele } \\
\text { groep }\end{array} \\
\end{array}$} & \multicolumn{3}{|c|}{ Kontrolegroep } \\
\hline D & $\begin{array}{l}\text { Voor- } \\
\text { toets }\end{array}$ & $\begin{array}{c}\text { Na- } \\
\text { toets }\end{array}$ & D & $\begin{array}{l}\text { Voor- } \\
\text { toets }\end{array}$ & $\begin{array}{c}\text { Na- } \\
\text { toets }\end{array}$ & D & $\begin{array}{l}\text { Voor- } \\
\text { toets }\end{array}$ & $\begin{array}{c}\text { Na- } \\
\text { toets }\end{array}$ & D & $\begin{array}{l}\text { Voor- } \\
\text { toets }\end{array}$ & $\begin{array}{l}\text { Na- } \\
\text { toets }\end{array}$ \\
\hline 1 & 18 & 23 & 6 & 16 & 18 & 1 & 18 & 20 & 6 & 15 & 13 \\
\hline 2 & 18 & 20 & 7 & 10 & 10 & 2 & 18 & 25 & 7 & 9 & 11 \\
\hline 3 & 21 & 24 & 8 & 10 & 11 & 3 & 20 & 26 & 8 & 16 & 15 \\
\hline 4 & 14 & 18 & 9 & 17 & 16 & 4 & 16 & 23 & 9 & 12 & 16 \\
\hline 5 & 20 & 22 & 10 & 15 & 16 & 5 & 21 & 25 & 10 & 13 & 14 \\
\hline Omv & $14-21$ & $18-24$ & & $10-17$ & $10-18$ & & $16-21$ & $20-26$ & & $9-16$ & $11-16$ \\
\hline Gem & 18,2 & 21,4 & & 13,6 & 14,2 & & 18,6 & 23,8 & & 13 & 13,8 \\
\hline
\end{tabular}

Nota: $\mathrm{D}=$ deelnemer, Omv = omvang; Gem = gemiddeld

Tabel 5 toon die sinne met neweskikking. Uit die tabel blyk dit dat die gebruik van neweskikkende voegwoorde deur die kontrolegroep vir beide narratiewe konstant gebly het (óf geen neweskikkende voegwoorde nie óf slegs een). Slegs enkele deelnemers in die eksperimentele groep het 'n verbetering in die gebruik van neweskikkende voegwoorde getoon. Die grootste hiervan was deelnemer 5 wat in die oorvertel van Op die strand in die voortoets een neweskikkende voegwoord getoon het en in die natoets vier. Hierdie is die enigste verskil wat moontlik as klinies beduidend beskou kan word, maar selfs hierdie verskil is nie so groot soos verwag sou word na ses weke se direkte instruksie nie. 
Tabel 5. Sinne met neweskikking

\begin{tabular}{|c|c|c|c|c|c|c|c|c|c|c|c|}
\hline \multicolumn{6}{|c|}{ DIE MIER EN DIE DUIF } & \multicolumn{6}{|c|}{ OP DIE STRAND } \\
\hline \multicolumn{3}{|c|}{$\begin{array}{c}\text { Eksperimentele } \\
\text { groep }\end{array}$} & \multicolumn{3}{|c|}{ Kontrolegroep } & \multicolumn{3}{|c|}{$\begin{array}{c}\text { Eksperimentele } \\
\text { groep }\end{array}$} & \multicolumn{3}{|c|}{ Kontrolegroep } \\
\hline D & $\begin{array}{l}\text { Voor- } \\
\text { toets }\end{array}$ & $\begin{array}{l}\text { Na- } \\
\text { toets }\end{array}$ & D & $\begin{array}{l}\text { Voor- } \\
\text { toets }\end{array}$ & $\begin{array}{l}\text { Na- } \\
\text { toets }\end{array}$ & D & $\begin{array}{l}\text { Voor- } \\
\text { toets }\end{array}$ & $\begin{array}{l}\text { Na- } \\
\text { toets }\end{array}$ & D & $\begin{array}{l}\text { Voor- } \\
\text { toets }\end{array}$ & $\begin{array}{l}\text { Na- } \\
\text { toets }\end{array}$ \\
\hline 1 & 0 & 0 & 6 & 0 & 0 & 1 & 1 & 1 & 6 & 1 & 1 \\
\hline 2 & 0 & 0 & 7 & 0 & 0 & 2 & 0 & 1 & 7 & 0 & 0 \\
\hline 3 & 0 & 0 & 8 & 0 & 0 & 3 & 1 & 2 & 8 & 0 & 0 \\
\hline 4 & 0 & 1 & 9 & 0 & 0 & 4 & 1 & 1 & 9 & 1 & 1 \\
\hline 5 & 0 & 0 & 10 & 0 & 0 & 5 & 1 & 4 & 10 & 0 & 0 \\
\hline Omv & 0 & $0-1$ & & 0 & 0 & & $0-1$ & $1-4$ & & $0-1$ & $0-1$ \\
\hline Gem & 0 & 0,2 & & 0 & 0 & & 0,8 & 1,8 & & 0,4 & 0,4 \\
\hline
\end{tabular}

Nota: $\mathrm{D}=$ deelnemer, Omv = omvang; Gem = gemiddeld

Tabel 6 toon die aantal sinne met onderskikking. Die kontrolegroep het weer 'n konstante telling (deurgaans geen onderskikkende voegwoorde) behaal, terwyl drie van die vyf lede van die eksperimentele groep in die natoetse meer onderskikkende voegwoorde gebruik het as in die voortoetse vir minstens een van die twee narratiewe. Waar daar wel 'n toename in die gebruik van onderskikkende voegwoorde was, was hierdie verskil egter telkens so klein (0 en 1 in die voortoets het telkens onderskeidelik 1 en 2 in die natoets geword) dat die verskil nie as klinies beduidend beskou kan word nie.

Tabel 6. Sinne met onderskikking

\begin{tabular}{|c|c|c|c|c|c|c|c|c|c|c|c|}
\hline \multicolumn{6}{|c|}{ DIE MIER EN DIE DUIF } & \multicolumn{6}{|c|}{ OP DIE STRAND } \\
\hline \multicolumn{3}{|c|}{$\begin{array}{c}\begin{array}{c}\text { Eksperimentele } \\
\text { groep }\end{array} \\
\end{array}$} & \multicolumn{3}{|c|}{ Kontrolegroep } & \multicolumn{3}{|c|}{$\begin{array}{c}\begin{array}{c}\text { Eksperimentele } \\
\text { groep }\end{array} \\
\end{array}$} & \multicolumn{3}{|c|}{ Kontrolegroep } \\
\hline D & $\begin{array}{l}\text { Voor- } \\
\text { toets }\end{array}$ & $\begin{array}{l}\text { Na- } \\
\text { toets }\end{array}$ & D & $\begin{array}{l}\text { Voor- } \\
\text { toets }\end{array}$ & $\begin{array}{l}\text { Na- } \\
\text { toets }\end{array}$ & D & $\begin{array}{l}\text { Voor- } \\
\text { toets }\end{array}$ & $\begin{array}{l}\text { Na- } \\
\text { toets }\end{array}$ & D & $\begin{array}{l}\text { Voor- } \\
\text { toets }\end{array}$ & $\begin{array}{l}\text { Na- } \\
\text { toets }\end{array}$ \\
\hline 1 & 0 & 1 & 6 & 0 & 0 & 1 & 0 & 0 & 6 & 0 & 0 \\
\hline 2 & 0 & 0 & 7 & 0 & 0 & 2 & 1 & 2 & 7 & 0 & 0 \\
\hline 3 & 0 & 1 & 8 & 0 & 0 & 3 & 0 & 1 & 8 & 0 & 0 \\
\hline 4 & 0 & 0 & 9 & 0 & 0 & 4 & 1 & 1 & 9 & 0 & 0 \\
\hline 5 & 0 & 1 & 10 & 0 & 0 & 5 & 0 & 0 & 10 & 0 & 0 \\
\hline Omv & 0 & $0-1$ & & 0 & 0 & & $0-1$ & $0-2$ & & 0 & 0 \\
\hline Gem & 0 & 0,6 & & 0 & 0 & & 0,4 & 0,8 & & 0 & 0 \\
\hline
\end{tabular}

Nota: $\mathrm{D}=$ deelnemer, Omv = omvang; Gem = gemiddeld 
Tabel 7 toon die voegwoorde wat in Die mier en die duif, soos vertel deur die navorser, voorgekom het en die frekwensie waarmee hierdie voegwoorde deur die deelnemers tydens die oorvertel van hierdie narratief gebruik is. Soos blyk uit die tabel het slegs een deelnemer uit die kontrolegroep 'n geteikende voegwoord (naamlik want) gebruik, en het hierdie voegwoord in beide die voor- en die natoets voorgekom. In die eksperimentele groep het slegs een deelnemer tydens die voortoets 'n geteikende voegwoord (voordat) gebruik. Hierdie voegwoord is egter nie deur dieselfde deelnemer of enige ander deelnemer in die natoets gebruik nie. Drie deelnemers in die eksperimentele groep het wel elk een voegwoord (want, omdat, en sodat) in die natoets gebruik. Hierdie geringe toename in die gebruiksfrekwensie van sommige geteikende voegwoorde word nie as klinies beduidend beskou nie.

Tabel 7. Voegwoorde geteiken deur Die mier en die duif en hul gebruiksfrekwensie

\begin{tabular}{|c|c|c|c|c|c|c|c|c|c|c|}
\hline \multirow{2}{*}{$\begin{array}{l}\text { Voegwoorde } \\
\text { geteiken }\end{array}$} & \multicolumn{5}{|c|}{ Eksperimentele groep } & \multicolumn{5}{|c|}{ Kontrolegroep } \\
\hline & D 1 & D 2 & D 3 & D 4 & D 5 & D 6 & D 7 & D 8 & D 9 & D 10 \\
\hline \multicolumn{11}{|l|}{ maar voor } \\
\hline \multicolumn{11}{|l|}{ maar na } \\
\hline want voor & & & & & & & & & 1 & \\
\hline want na & & & & 1 & & & & & 1 & \\
\hline voordat voor & & & 1 & & & & & & & \\
\hline \multicolumn{11}{|l|}{ voordat na } \\
\hline \multicolumn{11}{|l|}{ totdat voor } \\
\hline \multicolumn{11}{|l|}{ totdat na } \\
\hline \multicolumn{11}{|l|}{ omdat voor } \\
\hline omdat na & 1 & & & & & & & & & \\
\hline \multicolumn{11}{|l|}{ sodat voor } \\
\hline sodat na & & & & & 1 & & & & & \\
\hline \multicolumn{11}{|l|}{ aangesien voor } \\
\hline aangesien na & & & & & & & & & & \\
\hline
\end{tabular}

Nota: $\mathrm{D}=$ deelnemer

Die voegwoorde wat deur Op die strand geteiken is (en dus deur die navorser gebruik is tydens die vertel van hierdie narratief), asook die frekwensie waarmee die deelnemers hierdie voegwoorde gebruik het tydens die oorvertel van die narratief, kom in Tabel 8 voor. Soos in die geval van Die mier en die duif het slegs een deelnemer uit die kontrolegroep 'n geteikende voegwoord (weer eens want) gebruik, en het hierdie voegwoord in beide die voor- en die natoets voorgekom. In die eksperimentele groep is vier geteikende voegwoorde (maar, want, 
sodat, en sodra) ses keer deur die vyf deelnemers tesame in die voortoets gebruik, terwyl vier geteikende voegwoorde (maar, want, sodat, en omdat) altesaam 13 keer in die natoets gebruik is. Die mate waarin voegwoorde voor en ná direkte instruksie deur die eksperimentele groep gebruik is, het meer as verdubbel. Dit is egter nie duidelik of hierdie verdubbeling as klinies beduidend beskou kan word nie.

Tabel 8. Voegwoorde geteiken deur Op die strand en hul gebruiksfrekwensie

\begin{tabular}{|c|c|c|c|c|c|c|c|c|c|c|}
\hline \multirow{2}{*}{$\begin{array}{l}\text { Voegwoorde } \\
\text { geteiken }\end{array}$} & \multicolumn{5}{|c|}{ Eksperimentele groep } & \multicolumn{5}{|c|}{ Kontrolegroep } \\
\hline & D 1 & D 2 & D 3 & D 4 & D 5 & D 6 & D 7 & D 8 & D 9 & D 10 \\
\hline maar voor & & & & & 1 & & & & & \\
\hline maar na & & & & 1 & 2 & & & & & \\
\hline want voor & 1 & & 1 & 1 & & 1 & & & & \\
\hline want na & 1 & 1 & 2 & & 2 & 1 & & & & \\
\hline \multicolumn{11}{|l|}{ dus voor } \\
\hline \multicolumn{11}{|l|}{ dus na } \\
\hline \multicolumn{11}{|l|}{ terwyl voor } \\
\hline \multicolumn{11}{|l|}{ terwyl na } \\
\hline sodat voor & & & & 1 & & & & & & \\
\hline sodat na & & 2 & & 1 & & & & & & \\
\hline sodra voor & & 1 & & & & & & & & \\
\hline \multicolumn{11}{|l|}{ sodra na } \\
\hline \multicolumn{11}{|l|}{ aangesien voor } \\
\hline \multicolumn{11}{|l|}{ aangesien na } \\
\hline \multicolumn{11}{|l|}{ daarom voor } \\
\hline \multicolumn{11}{|l|}{ daarom na } \\
\hline \multicolumn{11}{|l|}{ omdat voor } \\
\hline omdat na & & & 1 & & & & & & & \\
\hline
\end{tabular}

Nota: $\mathrm{D}=$ deelnemer

\section{BESPREKING}

Die breë doel van hierdie loodsstudie was om vas te stel of 'n ses-week lange program van direkte instruksie 'n verhoging in die sintaktiese kompleksiteit van orale narratiewe, gemeet met ' $\mathrm{n}$ narratief-oorvertel taak, by graad 3-leerders tot gevolg sou hê. Daar is verwag dat ses weke se direkte instruksie oor die gebruik van voegwoorde 'n merkbare verskil sou meebring in die voor- en natoetsresultate van die eksperimentele groep vergeleke met die verskil in 
resultate van die kontrolegroep wat geen instruksie oor voegwoorde ontvang het nie, 'n resultaat wat dan met 'n meer uitgebreide studie gedupliseer sou kon word.

Daar is bevind dat die direkte instruksie slegs 'n verbetering in die natoets van die eksperimentele groep (vergeleke met dié van die kontrolegroep) meegebring het op een van die sewe metings wat op die oorvertelde narratiewe uitgevoer is. In terme van aantal Teenhede, produktiwiteit, GLU, en aantal neweskikkende en onderskikkende voegwoorde is daar geen beduidende verskil gevind ná direkte instruksie nie. Die hoeveelheid T-eenhede sou 'n toename kon toon indien daar 'n noemenswaardige toename in die gebruik van neweskikkende voegwoorde was, wat nie die geval was nie. Die feit dat produktiwiteit nie na direkte instruksie toegeneem het nie, is verstaanbaar as daar in ag geneem word dat 'n toename in die gebruik van voegwoorde nie noodwendig tot beduidend langer narratiewe sal lei nie. Dat ook GLU nie verhoog het nie, kan toegeskryf word aan twee feite, naamlik dat die produktiwiteit (d.i., aantal woorde) nie toegeneem het nie en dat verhoogde gebruik van onderskikkende voegwoorde (wat tot langer T-eenhede sou lei) nie plaasgevind het nie.

Sintaktiese kompleksiteit soos gemeet deur die SKS het wel 'n beduidende toename van die voor- na die natoets getoon by die eksperimentele groep, wat daarop dui dat direkte instruksie wel sintakties meer komplekse uitinge kan meebring. Die verandering kon toegeskryf word aan die poging tot die gebruik van voegwoorde deur die eksperimentele groep.

Frekwensietellings het getoon dat die gebruik van die voegwoorde wat deur die navorser aan die deelnemers gemodelleer is tydens die vertel van die narratief ook met direkte instruksie 'n verbetering getoon het. Hierdie toename was van so 'n aard dat dit as klinies beduidend beskou sou kon word, was dit nie die geval dat dit ses ure se direkte instruksie geverg het om die toename mee te bring nie.

$\mathrm{Na}$ aanleiding van die resultate kan gesê word dat die program van direkte instruksie nie 'n noemenswaardige verhoging in sintaktiese kompleksiteit (soos gemeet aan die hand van die sewe metings) van die naratiewe wat deur die geselekteerde graad 3-leerders oorvertel is, meegebring het nie. Verskeie redes kan hiervoor aangevoer word, waarvan die meeste metodologies is. 
Die eerste metodologiese rede wat vir die verkreë resultate aangevoer kan word, het met die steekproef te make. Hierdie studie was 'n loodsstudie met 'n baie beperkte aantal deelnemers. Dit bring mee dat die deelnemers nie as verteenwoordigend beskou kan word nie (nie van graad 3-leerlinge, Afrikaanssprekende kinders, of kinders van die ouers wat tot die lae-sosioekonomiese groep behoort nie). Dit beperk ook die veralgemeenbaarheid van die resultate.

Die tweede metodologiese rede vir die verkreë resultate handel oor die lengte van die program. Direkte instruksie is in 'n bestek van ses weke voltooi, in twee halfuur sessies per week, wat 'n totaal van ses ure uitmaak. Dit is moontlik dat 'n merkbare verandering in sintaktiese kompleksiteit van narratiewe eers na méér as ses ure se instruksie waargeneem kan word, 'n moontlikheid wat verder ondersoek sal moet word, onder andere weens die invloed wat die bevestiging van hierdie moontlikheid op terapiebeplanning kan hê.

'n Derde metodologiese rede rede vir die resultate mag te make hê met die aard van die program. Graad 3-leerders het moontlik nie die vermoë om vaardighede van een tipe taak (soos direkte instruksie) na 'n ander (soos narratief-oorvertel) oor te dra sonder dat hierdie oordrag doelbewus gefasiliteer word nie, 'n moontlikheid wat ook implikasies vir terapiebeplanning inhou.

Die vierde moontlike rede vir die verkreë resultate het te make met die narratiewe wat gebruik is in die voor- en natoetse. Geen kind in die toetspopulasie het enige van die twee narratiewe voorheen gehoor nie. Daar was dus nie bekendheid met die narratiewe voor die aanvang van die studie nie. Dieselfde twee narratiewe is egter vir die voortoets sowel as die natoets gebruik. Dit kon 'n leer-effek bewerkstellig het wat tot 'n verhoging in die deelnemers se SKStellings kon lei, veral aangesien slegs twee maande verloop het tussen die voor- en die natoets (terwyl Renfrew (1997) aanbeveel dat daar 'n tydperk van ten minste drie maande verloop voordat daar hertoetsing met die Renfrew Bus Story plaasvind). Indien 'n leer-effek egter teenwoordig was, sou 'n verbetering op die ander metings, en nie net in SKS-tellings nie, ook verwag word.

Soos die vierde rede het die laaste een ook te make met die narratiewe. Dit is moontlik dat die spesifieke narratiewe wat geselekteer is, suksesvol sonder die gebruik van voegwoorde 
oorvertel kan word. Dit kon dus wees dat die deelnemers nie voegwoorde gebruik het nie, omdat hulle nie daarvan bewus was dat daar van hulle verwag is om die narratiewe oor te vertel met voegwoorde, soos dié narratiewe wat aan hulle gemodelleer is, nie.

Selfs met al bogenoemde tekortkominge in ag geneem, is daar steeds 'n groter mate van oordrag van voegwoordgebruik van die direkte instruksie-aktiwiteit na die narratief-oorvertel taak verwag op grond van die tyd wat aan instruksie bestee is en die intensiwiteit van die instruksie. Hierdie tekort aan oordrag laat drie vrae ontstaan, naamlik (i) of hierdie populasie wel bloot ' $n$ reseptiewe taalagterstand het (soos aangetoon deur die ARW-resultate) of eerder taalgestremd was, (ii) of die tekort aan oordrag na die narratief-oorvertel taak moontlik toegeskryf kan word aan kulturele verskille in die wyse waarop stories vertel en oorvertel word, en (iii) of hierdie populasie genoegsame blootstelling aan die oorvertel van narratiewe gehad het om die taak wat die navorser van hulle vereis het met sukses te kon uitvoer. Rollins et al. (2000:229) noem egter dat kinders van elke kultuurgroep wat tot dusver bestudeer is wel narratiewe (in een of ander formaat) vertel en dat hierdie narratiewe almal die hoofkomponente van 'n narratief bevat, d.i., oriëntering, aksie, evaluering, en kodas (wat ook teenwoordig was in die narratiewe wat in hierdie studie gebruik is).

Die bevindinge stel 'n implikasie vir die kliniese praktyk voor. Daar word voorgestel dat spraak-taalterapeute doelbewus oordrag van aangeleerde vaardighede na narratiewe moet fasiliteer. Direkte instruksie was wel susksesvol indien die aanleer van voegwoorde en die gebruik daarvan in geïsoleerde sinne as die maatstaf vir sukses geneem word. Tydens die behandelingsprogram kon die navorser ontwikkeling by die eksperimentele groep waarneem. Hierdie deelnemers kon na drie sessies nie net voegwoorde gebruik om sinne te verbind nie, maar ook die gevolg van sinsamevoeging voorspel en mekaar help om beter gevormde sinne te produseer en swakker probeerslae te elimineer. Hul meta-linguistiese vaardighede, asook die groeps-interaksie en vertroue in mekaar se insig (wat nie een 'n fokus van hierdie loodsstudie was nie en dus nie in die resultate weerspieël word nie) het merkbaar van een sessie na die volgende verbeter. Ten spyte van die positiewe uitwerking van direkte instruksie, is sintaktiese vaardighede wat aangeleer is, nie na 'n nuwe konteks oorgedra nie. Dit impliseer dat spraak-taalterapeute oordrag moet fasiliteer deur waar direkte instruksie gegee word, 
hierdie instruksie op te volg met inoefening in 'n verskeidenheid aktiwiteite, soos geskrewe take, orale narratiewe, of beskrywings, wat langer is en groter kognitiewe uitdagings daarstel.

\section{GEVOLGTREKKING}

Hierdie loodsstudie het getoon dat 'n ses-week lange program bestaande uit direkte instruksie nie 'n verhoging in die sintaktiese kompleksiteit in narratiewe by graad 3-leerders tot gevolg gehad het nie. Aangesien hierdie studie 'n loodsstudie was, word daar aanbeveel dat die prosedure aangepas word en herhaal word met 'n groter groep deelnemers om sodoende vas te stel of vaardighede wat tydens direkte instruksie aangeleer word wel deur graad 3-leerders oorgedra kan word na take wat in die klaskamer van hulle verwag word, maar wat verskil van die take wat tydens die direkte instruksie gebruik is. Indien nie, behoort spraak-taalterapeute hul terapiemetodes te ondersoek en aan te pas om seker te maak dat hul kliënte nie bloot daarin slaag om sekere terapie-aktiwiteite uit te voer nie (en dus sukses op hierdie aktiwiteite die doel van terapie maak nie), maar dat kliënte inderdaad tydens terapie toegerus word met vaardighede wat tot verbeterde prestasie in akademies-verwante aktiwiteite sal lei. 


\section{VERWYSINGS}

Alant, E., H. Tesner, and E. Taljaardt. 1992. Narrative performance in context: Analysis and implications within a South African context. Child Language Teaching and Therapy 8(2): 188-204.

Buitendag, M.M. 1993. Afrikaanse Reseptiewe Woordeskattoets. Raad vir Geesteswetenskaplike Navorsing.

Crystal, D., P. Fletcher, and M. Garman. 1989. The grammatical analysis of language disability: A procedure for assessment and remediation. Second edition. London: Edward Arnold Publisher Ltd.

Goldstein, H. 1984. Effects of modeling and corrected practice on generative language learning of preschool children. Journal of Speech and Hearing Disorders 49(4): 389398.

Gummersall, D.M. and C.J. Strong. 1999. Assessment of complex sentence production in a narrative context. Language, Speech, and Hearing Services in Schools 30: 152-164.

Gutierrez-Clellen, V.F. and R. Hofstetter. 1994. Syntactic complexity in Spanish narratives: A development study. Journal of Speech and Hearing Research 37: 645-654.

Hunt, R. en A. Brychta. 1999. Op die strand. Kaapstad: OUP.

Klop, D. en S. Rumble. 2001. 'n Ondersoek na risikofaktore vir latere leesmislukking in 'n groep voorskoolse kinders: 'n Loodsstudie. Ongepubliseerde navorsingsverslag: Departement Spraak-Taal-Gehoorterapie, Universiteit Stellenbosch.

Krantz, F.M. 2001. Die effek van 'n dialogiese leesprogram op sintaktiese kompleksiteit. Ongepubliseerde navorsingsverslag: Departement Spraak-Taal-Gehoorterapie, Universiteit Stellenbosch.

Landgarten, H.B. 1981. Clinical art therapy. New York: Brunner/Mazel Publishers.

Lee, L. 1974. Developmental sentence analysis. Evanston: Northwestern University Press.

Louw, L. 2002. Die terapeutiese effek van piktografie op die ontwikkeling van narratiewe by 'n groep graad drie leerders. Ongepubliseerde navorsingsverslag: Departement SpraakTaal-Gehoorterapie, Universiteit Stellenbosch.

McCarthy, D. 1954. Language development in children. In L. Carmichael (ed.) Manual of child psychology. New York: Wiley. pp. 492-630. 
Milosky, L.M. 1987. Narratives in the classroom. Seminars in Speech and Language 8(4): 329-343.

Nippold, M. 1993. Developmental markers in adolescent language: Syntax, semantics and pragmatics. Language, Speech, and Hearing Services in Schools 24: 21-28.

Owens, R.E. 1999a. Language disorders: A functional approach to assessment and intervention. Third edition. New York: Allyn and Bacon.

Owens, R.E. 1999b. Language development: An introduction. Fifth edition. New York: Allyn and Bacon.

Pelligrini, A.D. 1985. Relations between preschool children's symbolic play and literate behavior. In L. Galda and A.D. Pelligrini (eds.) Play, language and stories: The development of children's literate behavior. Norwood: Ablex. pp. 79-97.

Renfrew, C.E. 1997. Bus story test: A test of narrative speech. Bicester: Winslow Press Ltd.

Rollins, P.R., A. McCabe, and L. Bliss. 2000. Culturally sensitive assessment of narrative in children. Seminars in Speech and Language 21: 223-234.

Segal, E.M. and J.F. Duchan. 1997. Interclausal connectives as indicators of structuring in narrative. In J. Costermans and M. Fayol (eds.) Processing interclausal relationships. Mahwah: Lawrence Erlbaum. pp. 95-119.

Smallman, S. and P. Nestling. 1993. Kom ons lees: Die mier en die duif. Braamfontein: MacMillan Boleswa.

Statistics South Africa. 1999. Census in brief. (No. 03-01-11-1996). Pretoria: Author.

Templin, M.C. 1957. Certain language skills in children. Minneappolis: University of Minnesota Press.

Vorster, J. 1980. Manual for the test of oral language production. Pretoria: HSRC.

Wagner, C.R., U. Nettelbladt, B. Sahlén, and C. Nilholm. 2000. Conversation versus narration in pre-school children with language impairment. International Journal of Language and Communication Disorders 35: 83-93.

Whitehurst, G.J., D.S. Arnold, J.N. Epstein, A.L. Angell, M. Smith, and J.E. Fischel. 1994. A picture book reading intervention in day care and home for children from low-income families. Developmental Psychology 30(5): 679-689. 


\section{BYLAAG A: AANGEPASTE WEERGAWE VAN DIE MIER EN DIE DUIF}

Eendag was daar 'n mier wat in die veld geloop het. Hy was vreeslik dors en daarom stap hy na die dam toe. Die dam is vol water en die mier kan daar lekker koel water drink. Die mier buk vooroor om van die koel water te drink, maar toe val hy binne-in die koue water. "Help my! Help my!" roep die mier bang, want hy kan glad nie swem nie.

Heel bo in die boom langs die dam sit daar 'n duif tussen die mooi groen blare. "Ek moet die arme mier gaan help," sê die duif. Hy pluk vinnig 'n groot groen blaar af voordat hy dit vir die bang mier afgooi. Die mier klim blitsvinnig op die blaar totdat hy na die wal van die dam toe dryf. "Dankie tog!" sê hy bly. "Ek het baie groot geskrik, want ek was baie bang dat ek gaan verdrink."

Skielik sien die mier 'n man met groot skoene wat al hoe nader kom. Die man dra 'n bruin sak en ook 'n gevaarlike geweer omdat hy na iets soek om te skiet. Toe die man die duif hoog bo in die boom sien, besluit hy om die arme duif te skiet. Hy lig sy geweer en mik versigtig na die duif toe, want hy wil nie mis skiet nie. "Ek moet gou 'n plan maak," sê Mier, want hy wil sy vriend help. Hy byt die man hard op sy been. "Eina!" skree die man kwaad, want die mier byt seer. Hy laat val sy geweer op die grond sodat hy vinniger kan weghardloop. Die duif vlieg uit die boom na die mier toe en gaan sit langs hom op die grond. "Baie dankie, liewe mier," sê die duif. "Omdat jy my gehelp het gaan ek vir altyd jou beste vriend wees." "Ag wat," sê die mier, "dis net 'n plesier, aangesien jy my ook gehelp het toe ek amper verdrink het." 


\section{BYLAAG B: AANGEPASTE WEERGAWE VAN OP DIE STRAND}

Emile en Charlene hou vakansie by die see. Hulle ma en pa wil uitrus; dus speel hulle eenkant op die strand. Hulle bou 'n dorp met paaie in die sand en speel met hulle karretjies.

Skielik hoor hulle iemand snork terwyl hulle nog speel. Hulle kyk rond en sien dat Pappa vas aan die slaap is. "Kom ons gooi vir Pappa met sand toe terwyl hy slaap," sê Emile. Charlene dink dit is 'n goeie plan, maar sy dink hulle moet dit stilletjies doen sodat Pappa nie wakker word nie. Emile en Charlene bou 'n sandkasteel bo-op Pappa. Hulle sit sy pet bo-op sodat hulle kan sien sodra Pappa beweeg.

"Kom ons gaan koop solank roomys, want Pappa sal seker nog lank slaap," sê Charlene. "Aangesien ons hard gewerk het, kan ons 'n ekstra groot roomys koop," sê Emile. Pappa slaap nog altyd daarom loop hulle bietjie rond. Emile kyk na die donkieritte, want hy hou van diere. Charlene kyk na die boot aangesien sy nie van donkies hou nie. Hulle loop toe verder en sien klein karretjies wat resies jaag, maar dit lyk nogals gevaarlik.

Hulle loop terug strand toe en toe skrik hulle, want Pappa se hoed dryf in die water. "Ag nee!" sê Charlene. "Pappa is weg," sê Emile. "Nee, is nie. Kyk! Daar is hy," sê Charlene. Sy word sommer kwaad omdat sy groot geskrik het. "Toemaar, toemaar," sê Pappa, "die hoed was net op 'n stok. Ek het maar net vir julle ook 'n poets gebak." Toe lag almal. Hierdie is 'n lekker vakansie. 


\section{BYLAAG C: VOORBEELDE VAN DEELNEMERS SE NARRATIEWE}

\section{Deelnemer 7 (voor instruksie)}

die mier het water gaan drink

toe val hy in die water

toe help die duif hom

en toe kom daar ' $n$ man

toe wil die man iets soek om te skiet

en toe wil hy die duif skiet

en toe byt die mier hom

toe hardloop hy

toe kom sit die duif by die mier

toe sê hy vir die mier hy sal vir ewig sy

vriend bly

\section{Deelnemer 9 (voor instruksie)}

Emile en Charlene hou vakansie

hulle gooi vir Pappa toe met die sand

Pappa slaap

hulle gaan koop vir hulle 'n roomys

Emile kyk na die donkies en Charlene kyk

na die boot

hulle kyk na die karretjies

hulle dink dit is gevaarlik

Emile en Charlene sien Pappa se hoed dryf

in die water

o, nee sê Charlene

Charlene is kwaad vir Pappa, want Pappa is weg

\section{Deelnemer 7 (na instruksie)}

die mier het water gaan drink by die dam

toe val hy in die water

toe help die duif hom met 'n blaar

en toe kom daar 'n man

toe wil die man iets soek om te skiet

en toe wil hy die duif skiet

en toe byt die mier hom op sy been

toe hardloop hy weg

toe kom sit die duif by die mier op die

grond

toe sê hy vir die mier hy sal vir altyd sy

vriend bly

\section{Deelnemer 9 (na instruksie)}

Emile en Charlene hou vakansie by die see

hulle gooi vir Pappa toe met sand

Pappa slaap

hulle gaan koop vir hulle 'n groot roomys

hulle is moeg gespeel

hulle wil gaan rondloop

Emile kyk na die donkies en Charlene kyk

na die boot

hulle kyk na die karretjies en dink dit is

gevaarlik

Emile en Charlene sien Pappa se hoed dryf

in die water

aggenee sê Charlene

Charlene is kwaad vir Pappa, want Pappa

is weg

nee daar is hy 
